\title{
Responsibility Of Travel Agency Of Losses That Are Experienced By Service Users Consumer
}

\author{
Desak Komang Devi Karina Evansa, I Ketut Widia, I Wayan Rideng, \\ \{karinaevaa15@gmail.com\} \\ Program Magister Ilmu Hukum, Universitas Warmadewa Denpasar. 2019.
}

\begin{abstract}
This study aims to examine the responsibility of a travel agency for consumers of service users who suffer losses in service and to examine the procedure to get compensation for service users if experienced a loss. The method used in this study is normative method which carried out by examining library materials or primary legal material and secondary legal material. The results of the study showed that the responsibility of travel agents for consumers of service users who experience losses in service is by paying attention to the principles of legal protection against consumers, it is the obligation of business operators to replace losses experienced by consumers who in this case are tourists, which travel agents are responsible for the safety of tourists who travel based on the tour packages sold so that if there is a loss on the part of the service users due to errors or negligence of the company then it must be compensated as the principles of accountability stipulated in the Law on Consumer Protection. Moreover, procedure for obtaining compensation for service users if experienced losses through several stages, namely: the first stage, the heirs of the victims of the accident contact the police to then apply for compensation. The second stage is the victim and the heirs of the victim fill out a letter of compensation for the accident provided free of charge by P.T. Jasa Raharja (Persero). To get compensation, the victim or the heirs of the victim must meet the requirements requested by P.T. Jasa Raharja (Persero).
\end{abstract}

Keywords: Responsibility, Travel Agency, Loss, Service Users

\section{Introduction}

Various legal products and policies taken by the government in the field of tourism have so far not been able to provide a conducive climate to support the growth and development of unhealthy national tourism businesses among tourism companies and still find operational obstacles in the field such as the conditions of road infrastructure and facilities and to damage tourism objects and attractions that are not well maintained, and sometimes poor coordination between various parties involved.

To overcome this, travel agents need to maintain the quality of their services to customers and travel agents as work partners. The existence of a Tourist Travel Bureau in Bali has been specifically regulated in the Regional Regulation of Bali Province Number 1 of 2010 concerning Tourism Travel Services (Peraturan Daerah Provinsi Bali Nomor 1 Tahun 2010 
tentang Usaha Jasa Perjalanan Wisata). In Article 1 Number 13 of this Regional Regulation, it is stated that the tour travel agency business includes the business of providing travel planning services and/or services and services for tourism, including the administration of worship trips. Meanwhile, in Article 6 point 1, it is stated that one of the activities of the Tourist Travel Agency is to provide transportation/tourist transportation services.

In its aim to plan tourist travel activities, the Travel Agency often organizes various forms of tour packages to attract tourists who will come to a tourist area. These packages include hotel accommodation services, restaurants, and various other forms of tourism businesses. However, the existence of tour packages offered by these Travel Agencies is often not supported by a clear tourist safety protection factors. It is very rare to see special agreements made in writing between the Tourist Travel Agency and Tourists regarding the safety of the tourists themselves. Whereas in Article 26 point d of Law Number 10 of 2009 concerning Tourism (Undang-Undang Nomor 10 Tahun 2009 tentang Kepariwisataan) it has been clearly stated that Tourism Entrepreneurs are obliged to provide comfort, friendliness, security protection, and tourist safety. Whereas in Article 11 point 1 Letter a in the Regional Regulation of Bali Province, only states that Usaha Jasa Perjalanan Wisata Entrepreneurs are obliged to provide protection to tourists, in the form of guarantees of safety and security as long as these tourists are in Bali. However, starting April 11, 2014, the Government has set out the Standards of Tourism Travel Services through the Minister of Tourism and Creative Economy Regulation of the Republic of Indonesia Number 4 of 2014. In Article 9 paragraph (4) letter a it has been stated that business standards for the Travel Agency include 3 (three) aspects namely 1) Products, which consist of 20 elements, 2) Services, which consist of 7 elements, 3) Management, which consists of 11 elements.

This study has similar study that have been conducted by some researchers, such as in [3]; [4]; [5]. The research conducted by [3] aims to examine the legal liability of transportation services companys in giving maximal service and compensation to consumer. The finding showed that it can affecting a loss of time, energy or financial by consumer. In that case, transportation campanys can be told "wanprestasi". In this situation consumer can claim an indemnation and compensation in the form of replacement of goods and/or service if which is accepted disagree with agreement according to Article 4 point $h$ Undang-undang Perlindungan Konsumen. [4] in her research focused on to find out to what extent business enterprise shoud be held liable due to consumers'loss as a result of the application of standard form contract. The results of this study showed that the business enterpreuner is strict liable on the consumers' lost as a result of the application of standard form contract. Furthermore, the study of Muthiah (2017) aims to examine the responsibilities of business consumers to consumer concerning food security in consumer legal protection. The results showed that the responsibility of entrepreneurs is the responsibility that is based on the harm caused on the consumers and the consumers in this case have to prove the mistake of the entrepreneur. However, there is another alternative of responsibility that ease the consumers, which is called strict liability. This kind of responsibility is a form of risk from the entrepreneur and proving the mistakes should use reverse proof system, in which the entrepreneur is responsible to prove their own mistakes in the food production.

Building on the background and the latest related studies above, thus this study aims to examine the responsibility of a travel agency for consumers of service users who suffer losses in service and to examine the procedure to get compensation for service users if experienced a loss. 


\section{Methods}

This research used normative legal research. Normative Legal Research is research conducted by examining library materials or primary legal material and secondary legal material. Normative research is conducted because of the obscurity of the norms of Government Regulation Number 67 of 1996 concerning the Implementation of Tourism (Peraturan Pemerintah Republik Indonesia Nomor 67 Tahun 1996 tentang Penyelenggaraan Kepariwisataan) with Law Number 8 of 1999 concerning Consumer Protection, (UndangUndang Nomor 8 Tahun 1999 tentang Perlindungan Konsumen) which in Part Two Article 7 of Act Number 8 of 1999 only regulates the provision of compensation, compensation and/or replacement if the goods and/or services received or utilized are not in accordance with the agreement, without specifying how the procedure must be taken by the consumer to request the compensation, whereas to obtain such compensation or loss, the consumer is required to undergo a compensation application procedure.

\section{Results And Discussion}

\subsection{Responsibility of Travel Agency Between Consumers of Service Users Who Have Losses in Service}

Based on the Government Regulation of the Republic of Indonesia Number 67 of 1996 concerning Implementation of Tourism Paragraph 1 Article 10 concerning Travel Agency Services Business states that:

1. Mandatory travel agency:

a. Fulfill the type and quality of components of tour packages that are packaged and/or promised in tour packages.

b. Providing optimal service for tourists who place orders, arrange documents and carry out trips through travel agents

2. The travel agency is responsible for the safety of tourists traveling on tours based on the tour packages it sells.

If a violation occurs due to negligence committed by the tour and travel agency, then the travel agent's business permit may be revoked by the local Regent/Mayor with considerations taken.

1. Business license can be revoked if:

a. Not fulfilling the stipulated requirements for the business of travel agents and tour travel agents.

b. Not doing business activities for 2 (two) consecutive years.

c. Conduct activities that conflict with applicable regulations/provisions.

d. Not fulfilling the obligation to submit LKU to the Regent/Mayor.

e. It was found convincing things from the results of local inspection to carry out sanctions in accordance with the applicable provisions

2. Revocation of business licenses can be done after first being given 3 (three) consecutive written warnings within 90 (ninety) working days.

3. In addition to sanctions for revocation of business, the recipient/holder of a business permit for a travel agent and a travel agent may also be subject to other sanctions in accordance with the applicable laws and regulations. 
Talking about the responsibilities of business travel agents can not be separated from who is responsible for actions to whom the deed can be covered and whether each person who commits an act where the consequences of his actions can cause harm to the person, can be justified by the maker. Violating the law or the responsibility of legislation, it means that the responsibility is borne by the person who commits an act that violates the law where the result of his actions is what creates a responsibility where the responsibility must be borne by itself. Both the consequences of his actions lead to the existence of a responsibility where the responsibility must be borne by him alone. Both of the actions that violate the law are desired or not desired by the maker or in the sense because they are not careful or negligence causes harm to others. Likewise, the responsibility of a producer for the goods produced. Producers are responsible for the goods they produce that are circulating in the market and reach the consumers as those who use or use product goods from producers.

Consumer protection in Indonesia can be said to have become a social system that cannot be separated from various things, especially seen from the point of economic law. As one of the economic objects, consumer problems do not escape the problems of rights and interests, which need attention, especially in relation to aspects of the management of goods and services. By paying attention to the principles of legal protection against consumers, it is the obligation of business operators to replace losses suffered by consumers who in this case are tourists.

\subsection{Procedures for getting damages for service users if you have loss}

Service users are anyone who uses goods and/or public transportation services to meet their own and other people's interests. Judging from its position in the agreement to transport people, passengers are people who tie themselves to pay for transportation costs, [8].

In this perspective, the position of service users is as consumers, because service users are the legal subjects of service users, who are intended for themselves, where users of these services are not traded again. Service users in their position as consumers have rights formulated in Article 4 of UUPK, namely.

a. The right to comfort, safety and safety in consuming goods and/or services;

b. The right to choose and get goods and/or services in accordance with the exchange rate and conditions and guarantees promised;

c. Right to information that is correct, clear and honest regarding the condition and guarantee of goods and/or services;

d. The right to be heard opinions and complaints about the goods and/or services used;

e. The right to get advocacy, protection, and efforts to properly resolve consumer protection disputes;

f. The right to get guidance and education for consumers;

g. The right to be treated or served correctly and honestly and not discriminatory;

h. The right to receive compensation, compensation and/or substitution, if the goods and/or services received are not in accordance with the agreement or not as appropriate;

i. Rights stipulated in other statutory provisions.

Consumer rights as mentioned in Article 4 of UUPK are broader than the basic rights of consumers as first stated by President of the United States J.F Kennedy at the congress on March 15, 1962, which consists of.

a. Right to obtain security;

b. Right to vote; 


\section{c. Right to get information;}

d. Right to be heard, [9].

In connection with the occurrence of accidents of users of road services and traffic, the victims or the heirs of accident victims of service users and travel agents, submit claims for compensation to P.T. Jasa Raharja (Persero) Representative of Bali in accordance with procedures stipulated by Law Number 33 of 1964 and Law Number 34 of 1964 in conjunction with Government Regulation Number 17 of 1965 and Government Regulation Number 18 of 1965. The procedures for filing claims for compensation for accident victims of service users and travel agents are as follows:

1) First Stage: Heirs or victims of accidents contact the Police office in this case the local Police Traffic Unit (SATLANTAS POLRES), which then goes to the One Roof Single Administration (SAMSAT) office or P.T. The nearest Jasa Raharja (Persero), to then submit a compensation request. Heirs or victims fill out compensation forms from P.T. Jasa Raharja (Persero) that has been provided. In the submission form there are two parts, namely:

a. The first part is filled by heirs or accident victims regarding the name, relationship with the victim, address, occupation, gender, status, nature of the injury.

b. The second part, the form is filled in by P.T. Jasa Raharja (Persero), which is in the OneStop Single Administration System (SAMSAT), contains cases of accidents, accidents, the identity of the vehicle involved, the identity and nature of the victim's injury, and accident conclusions about the scope of the guarantee.

2) Second Stage

Based on information obtained by Jasa Raharja from the victims and their heirs and after Jasa Raharja provided an explanation of the procedure for requesting compensation for the accident to the victim. The next step the victim and the heirs of the victim fill out the compensation letter that is provided free of charge by P.T. Jasa Raharja (Persero), by attaching:

a) Information on traffic accidents signed by Jasa Raharja officers in the form of police reports and sketches of the accidents that occurred, both for victims of motor vehicle accidents, telegrams or news of accidents from P.T. Kereta Api (Persero). News of accidents from the captain/martyrdom officer and/or other authorized officials to crash ships/rivers/lakes and crossings and aircraft.

b) Health information from doctors, Community Health Centers (PUSKESMAS) or hospitals, where victims are treated or undergoing treatment. This health information contains injuries that outline contains an explanation of the identity of the treating physician, an explanation of injury, or injuries suffered by the victim, diagnosis of the condition and relief measures that have been or will be carried out against the victim.

In the event that the victim dies, the information attached is a death certificate from the doctor of the hospital where the victim was treated. Specifically regarding this matter, other necessary equipment is the statement of heirs. This information must be filled in and signed by the local Village Head or the authorized official who explains: the identity of the victim and the heir of the victim. To get compensation, the victim or the heirs of the victim must meet the requirements requested by P.T. Jasa Raharja (Persero). For completeness, proof documents must be submitted as follows:

a) In the case of death:

1) The verbal process of traffic police or other authorities regarding accidents that have occurred with the transportation equipment concerned, which resulted in the death of the heir. 
2) Decision of a judge or other authorized party regarding inheritance concerned.

3) Doctor's certificates and other evidence deemed necessary for the ratification of the facts of death that occurred, the cause of death relationship with the use of transportation equipment and things that determine the amount of payment of funds that must be given.

b) In permanent disability or injury

1) The verbal process of traffic police or other authorized persons regarding accidents that have occurred with the transportation equipment concerned, which results in permanent disability/injury to the claimant.

2) A doctor's certificate of the type of permanent/injury defect that has occurred as a result of an accident of service users and travel agents.

3) Other proof documents deemed necessary for the ratification of the fact of permanent disability/injury with the use of transportation equipment, and matters that determine the amount of payment of funds that must be given.

To get a guarantee of accident insurance for service users and accident of travel agents, in addition to the information above, other evidences that must be attached such as:

1) Police report along with a plan for a crime scene (TKP) or a report of the authorities;

2) Receipt of genuine and legal treatment and medical expenses in the event the victim is injured;

3) Identity Card (KTP) or other valid identity;

4) Birth Certificate or Certificate of Birth known;

5) Marriage Certificate;

6) Family Card (KK);

7) Description of permanent/injured disability from a doctor.

In a travel agency accident, anyone who is outside the travel agency's transportation that controls the victim will be given the right to payment of the travel agent's accident fund. Fund payments are given in the following cases:

1) The victim dies, within 365 days, after the occurrence of the related accident;

2) The victim gets a permanent disability, within 365 days after the occurrence of the related accident;

3) The costs of medical care and treatment that are issued from the first day after an accident, for a maximum of 365 days;

4) The death toll does not have an heir, to the party who organizes his burial, is given compensation for burial fees.

\section{Conclusions}

Based on the findings in the study over the execution of guarantee of land-bound Dependent Rights online, then it can be summarized that 1) the responsibility of a travel agent for consumers of service users who experience losses in service is to pay attention to the principles of legal protection against consumers. This responsibility includes responsibility for the safety of service users. This is done by insuring service users in accordance with the agreement. In addition, the responsibility of the Travel Agency also covers the safety of property carried by service users. If the luggage is lost or damaged, the service user has the right to get compensation. 2) Procedure for obtaining compensation for service users if they experience losses through several stages, namely: First stage; the heirs of the victims of the accident contact the police to then submit a compensation request. The second stage is the 
victim and the heirs of the victim fill out a letter of compensation for the accident provided free of charge by P.T. Jasa Raharja (Persero). To get compensation, the victim or the heirs of the victim must meet the requirements requested by P.T. Jasa Raharja (Persero).

\section{References}

[1] "Peraturan Daerah Provinsi Bali Nomor 1 Tahun 2010 tentang Usaha Jasa Perjalanan Wisata."

[2] "Undang-Undang Nomor 10 Tahun 2009 tentang Kepariwisataan."

[3] I. T. Nur, "Tanggung Jawab Hukum PelakuUsaha Jasa Transportasi Dalam Memberikan Pelayanan Maksimal dan Kompensasi Kepada Konsumen," RisalahHUKUM Fak. Huk. Unmul, vol. 2, no. 2, pp. 105-111, 2006.

[4] R. Supriyatni, "Tanggung Jawab Pelaku Usaha PT. Telekomunikasi indonesia Tbk. atas Penggunaan Perjanjian Baku Dihubungkan dengan Undang-undang Nomor 8 Tahun 1999 tentang Perlindungan Konsumen," Sosiohumaniora, vol. 9, no. 3, pp. 226-238, 2007.

[5] A. Muthiah, "Tanggung Jawab Pelaku Usaha kepada Konsumen tentang Keamanan Pangan dalam Perspektif Hukum Perlindungan Konsumen," Dialogia Iurid. J. Huk. Bisnis dan Investasi, vol. 7, no. 2, p. 1, May 2017.

[6] "Peraturan Pemerintah Republik Indonesia Nomor 67 Tahun 1996 tentang Penyelenggaraan Kepariwisataan."

[7] "Undang-Undang Nomor 8 Tahun 1999 tentang Perlindungan Konsumen."

[8] M. Abdulkadir, Hukum Pengangkutan Niaga, V. Bandung: PT. Citra Aditya Bakti, 2013.

[9] Hondius, Konsumentenrecht Praeadvis in Nederlandse Vereniging voor Rechtsverlijking. Kluwer-Deventer, 1972. 